\title{
Марианна Эрман
}

\section{МOE ВСТУПИТЕЛЬНОЕ САОВО*}

Тот, кто вступает на общественный пост, обычно произносит речь, в которой рекомендует себя своей аудитории. Почему бы и писательнице, после долгого перерыва снова взявшейся за перо, не сделать милостивым читательницам благоговейный поклон, тем более что она имеет дело с более многочисленной публикой, чем привычные ораторы. - Конечно, сколько людей, столько мнений! Эта ужасная поговорка, которая сразу начинает обременять мое сердце, как только я приближаюсь к письменному столу, чтобы по повелению особенной, не очень отрадной судьбы, сменить швейную иглу на перо 1 ! - Однако я полностью признаю, что если бы все женщины хотели заниматься тем, что практикую я, тогда в нашем добром мире царил бы совершенно невыносимый беспорядок'

Однако нет правил без исключения. - Я строго планирую свой день, лишь изредка появляюсь в обществе, проворно расправляюсь с моим скромным домашним хозяйством; детей

* Перевод подготовлен по изданию: Ehrmann, Marianne, Meine Antrittsrede. In: Amaliens Erholungsstunden. Teutschlands Töchtern geweiht von Marianne Ehrmann, Stuttgart (im Verlag der Expedizion des Beobachters und gedrukt bei den Gebrüdern Mäntlern) Tübingen 1790,Bd.I, Heft 1, S. 1-11.

1 "Сменить швейную иглу на перо" - метафора, часто встречавшаяся у писательниц конца XVIII в. В Аанном случае Марианна Эрман заявляет, что к писательской деятельности ее в первую очереАь подтолкнули сложные финансовые обстоятельства.

2 В настоящем высказывании Эрман акцентирует внимание на своей иск^ючительности, определенно негативной; она - иск^ючение из правил, элемент нарушения общественного порядка.

Перевод: Вероника Андреевна Аумачева, студент магистратуры Российского Государственного Гуманитарного Университета (РГГУ), vdumacheva@bk.ru DOI: 10.32608/2307-8383-2019-27-359-368 
у меня нет, поэтому мне остается достаточно времени для работы ${ }^{3}$. Стало быть, следует решиться. - Я хочу попробовать развлечь и обучить моих любезных читательниц, насколько это в моих силах. Только об одном я должна попросить вас заранее - чтобы вы простили мне мои порой чересчур грубые и жестокие высказывания. Простите мне тот факт, что порой, когда этого требует необходимость, я не говорю приятных слов, упоминая приставшие ко мне и моему полу пороки, простите, что временами взмахиваю плетьми сатиры, размышляя над зловещим уроном, препятствующим утонченному образованию. Для меня было бы наивысшей честью посодействовать развитию этого образования! Моя добрая воля жаждет вашего милостивого снисхождения, а признание моих собственных ошибок подготовит Вас к пути самоотречения. Ведь только взгляните: если бы хотя бы одна из вас оказалась бы настолько ограниченной, чтобы оскорбиться каким либо сатирическим выпадом, - который ни в коей мере не направлен на отдельных личностей, - как бы громко могли бы посмеяться над этой слабостью всезнающие мужички, заключив бы из этого, что в наших женских головках действительно так же пусто, как это обычно выглядит. Мужчины смеялись бы, оставшись при убеждении, что мы не в силах выдержать удары плетьми сатиры и более чем заслуженные упреки моралистов. Этих всезнаек позабавила бы их уверенность в том, что мы совершенно не обладаем силой духа, что раны, нанесен-

3 Подобная стратегия "оправдания" - один из главных мейтмотивов женской митературы в Германии конца XVIII в. (См. об этом подробнее: Kirstein. 1997: 75). Занятие публицистикой представлялось практически невозможным в привычном кругу женских обязанностей - ведении хозяйства (пусть даже условном, как в аристократической среде) и исполнении роли матери и супруги. Конкретно в случае Марианны Эрман можно заметить смену парадигмы: вместо воспитания Аетей она сосреАоточилась на воспитании своего пола. 
ные нам упреками, небрежным воспитанием, убеждением в женском бессилии, невозможно исцелить болезненным лечением. Им кажется, что мы словно изнеженные куклы моментально начинаем стонать, плакать, сопротивляться и даже браниться, когда дело доходит до какой-либо незначительной операции, которой вообще еще достоин наш глубоко оскорбленный пол. - O горе, как злорадно посмеивался бы этот отряд мужичков над этими открытиями и хвастался бы ими повсюду! —

Но рано смеяться, вы, венцы творения! - Я знаю, мой пол значительно лучше, у него нет недостатка в доброй воле, чтобы стать тем, чем бы он мог и должен был бы стать, если бы имел на то возможность. Нашему полу уделяется очень мало внимания. Так мало внимания уделяется его воспитанию и образованию, что практически все отдается на произвол старых привычек и укоренившихся предрассудков! Матушка была в неведении важных вещей, следовательно, и дочери не было дозволено знать ничего важного. Это те печальные последствия, которые препятствуют полным надежды девушкам. Но могло бы случиться так, что матушка все же обладала достаточным разумом, чтобы вследствие строго самопознания и искусного размышления о женских обязанностях сделать счастливым своего супруга, мудро вести домашнее хозяйство и заботиться о детях. Она бы могла выполнять общественные обязанности иным образом, не посредством машинальной, необдуманной деятельности ${ }^{4}$. Она могла бы быть мудрой матерью, обходительной супругой, бравой и остроум-

4 Метафора машинальности, неосмысленной повторяемости жизни часто встречается в женской митературе и китературе о женщинах позАнего XVIII в. Во многих случаях эта метафора была сопряжена с призывами к пересмотру насущного А^я эпохи вопроса женского образования, к оживлению, "одушевлению" женской интемлектуальной сущности. 
ной компаньонкой, однако воплощению этого способствуют лишь единицы мужчин! Они довольны, когда их жены не отличаются в мышлении от служанки, когда они не обладают собственной волей в поступках, а лишь прелестно подражаю тому, чему их наставляла в те самые «темные времена» бабушка. Они удовлетворены, когда в разговорах с женами их тянет зевать, ведь скука от этих разговоров дает им полное право проводить свое время вне дома. Они довольны и при этом спокойны, когда их жены являются сплетницами, клеветницами, задирами, кокетками и хулиганками, когда они под самым хвастливым именем доброй домохозяйки в душе являются лишь жалкими калеками, по своему рассудку неизменными дурочками, а по своим манерам - хулиганистыми созданиями. - Я утверждаю, большинство мужчин удовлетворены, когда их дочери следуют славным шагам матери; если их чада читают кулинарную книгу, какой-либо бессмысленный молитвенник или даже сентиментальный роман, который портит их разум и отравляет их сердца; они спокойны, когда молодая гусыня обзаводится мужем, который женится на ее деньгах, репутации или милом кукольном личике (которому ему довольно долго пришлось нашептывать приятнейшую чепуху); когда вся жизнь дочери лишь сводится к замужеству, воспитанию детей; когда она способна следить за собой, немного готовить, вязать и болтать о занятных вещах. - От таких печальных порядков у нас можно наблюдать бесконечные злоупотребления в отношении нашего пола, ошибки в воспитании, первенство глупости. Это приводит к тому, что все чаще слышны жалобы от тех достойнейших мужчин, которые желали бы улучшить наш пол и которые справедливо могут требовать этого5! 
Мне очень жаль, что я вынуждена выставлять мое открытие на такое широкое обозрение; я долго сдерживала себя с моими тайными наблюдениями и, наконец, я получила серьезную возможность замолвить об этом значимое словечко!

Посмею упомянуть еще одну неправомерность, которая касается женского образования. Я знаю мужчин и женщин из старого арсенала глупости, которые являются жертвами банального предрассудка: все, что способствует развитию женской культуры, является излишним и смехотворным, так как несет в себе опасность превратить женщин в слишком ученых особ. Господи, до чего абсурдны и неразвиты у этих людей представления о женщине, которая мыслит и должна мыслить, если она не хочет превратиться в безжизненную машину. Как они заблуждаются в своих представлениях об эрудированной женщине, которая якобы всю жизнь проводит за чрезмерным обучением, что ведет ее к полной неспособности к выполнению женских обязанностей, к отходу от женской природы и домашнего счастья. Почему путают одно с другим ${ }^{6}$ ? Отчего так сильно общественное стремление, перекры-

программные преАложения по вопросу преобразований в рамках "женского вопроса", в частности, относительно системы женского воспитания и образования. (См., например: Hippel. 1794; Hippel. 1801).

6 ПоА "эрудицией" в Аискурсе раннего Просвещения подразумевалось нечто иное, чем то, что стояло за этим термином к концу XVIII столетия. "В то время как понятие "эрудиция" к началу XVIII в. еще использовалось позитивно - как всестороннее образование, широкие знания и особые способности к наукам [...], - к концу века оно коннотировалось как уничижительное обозначение и служило синонимом сухой книжной начитанности". (См.: Böhmel-Fichera. 1996: 144). "С середины столетия, а именно с внедрением сентиментального образа женщины [...] и последующими за этим экономическими и правовыми ограничениями в положении женщины, понятие эрудиция стало рассматриваться как недопустимое применительно к женщине. <...> K 1790 г. определения "ученая" или "эрудированная" вызывают мишь шок и страх, которых Аолжна была опасаться ^юбая женщина, которой была важна ее репутация". (См.: Querelles. 1996: 16). 
вать путь мыслящим молодым девушкам к домашним и светским добродетелям лишь оттого, что время от времени какой-либо ученой даме нравится избегать этих добродетелей посредством менее подходящей для нее деятельности? - Как, ради всего святого, возможно, что это глупое заблуждение все еще так активно пропагандируется обществом и утверждается во вред нашим молодым девушкам? - Неужели этим упрямым, безрассудным всезнайкам хочется или просто нравится не понимать разницу между ученой педанткой и рассудительной мыслительницей, которая осознает необходимость размышления о своем предназначении? - Как болезненно действует это несправедливое непреклонное предубеждение о представительницах женского пола, которых тем самым пытаются отринуть от должного образования; ведь разница лежит в словах, и понятие содержит в себе как полезную, так и бесполезную цель. -

Но эта жалкая ирония, это заржавевшее предубеждение, которое во многих обществах является лишь крикливым недоразумением, этот кричащий и упрямый приказ не должен заставить моих читательниц пасть духом и далее следовать путем, который указан нам мыслящими справедливыми мужчинами. - Несмотря на все предрассудки, мы хотим повеселить наши головки, очистить наши души от скверного и научиться должным образом выполнять наши обязанности посредством чтения правильных книг и общения с разумным обществом. - Как радуется мое сердце, когда на своем пути я встречаю образованную женщину, которая мыслит и рассуждает. Особенно радует меня возможность, узнать ее поближе. Как сердечно я протянула бы ей руку, с каким великим энтузиазмом примкнула бы к ней и прижалась бы, полная сестринских чувств. Как же много девушек блистает лишь в своем укрытии, просто не отваживаясь вынести свое 


\section{Марианна Эрман Мое вступительное слово}

сокровище в свет. В этом им препятствует их ошибочная скромность или сдерживающий страх, ведь они уже заранее убеждены, что зависть и язвительный смех глупости давно поджидают в засаде, чтобы забросать их грязью7.

В каждом городе у его общества есть свой особенный тон, своя собственная рутина, которая, однако, часто является не самой поучительной. Случается, что в общество вступает та, что правильнее размышляет, говорит на более чистом немецком, в своих высказываниях выступает более открыто и естественно, свободно от сердца выражает свое мнение, а не просто поддакивает, не в состоянии с основанием опровергнуть мнение оппонента. Тогда из укрытия выступают ее менее просвещенные и образованные сестры и нападают на нее за ее спиной: досаждают духом клеветы, искажают и передергивают ее слова, всячески обременяют ее разной бессмыслицей. Они испытывают оскорбление уже просто от того, что эта девушка знает больше, чем они, за что ей приходится терпеть жестокие приступы злобы, уже давно таившейся в оскорбленных дамах. Я знаю уже довольно многих достойных женщин, обремененных общественными насмешками, по причине того, что они отважились укрепить свой разум и выделиться из повседневного общества своей речью и мышлением.

Это также одно из тех варварских препятствий, которые стоят на пути славных девушек, стремящихся вырваться на свет, расширять свои знания. В наших жалких женских обществах, где, как правило, только и делают, что едят, пьют, сплетничают или играют, невозможно ввести более возвышенный тон, нежели тот, который господствует на данный

7 ЗАесь подчеркивается яркая тенденция высмеивания, порицания и непринятия "ученых" женщин в обществе рассматриваемого исторического контекста. 
момент. 0, это одно из тех невыносимых препятствий, которые стоят на пути женского образования и затрудняют его распространение! -

Но этим жалким препятствиям, этим выродкам вероломного невежества и бледно-желтой женской зависти не удастся сломить сильную, благоразумную девушку, в которой живет большая мужественная душа. Они не остановят ее в благородной цели, бесстрашно способствовать просвещению общества и действовать для всеобеего блага. Она должна и будет сочувственно и с благородной гордостью улыбаться всем этим препятствиям. Ее будут вести пыл и сила духа, а также убеждение, что ею выбран наилучший путь, который приведет к твердому противостоянию предрассудкам и их искоренению из общественного сознания. А для нее эти предрассудки - всего лишь шипы, которые могут незначительно поранить ее кожу. Ей не должны мешать женская трусость, старинные предрассудки, глупые возражения сверхразумных матрон. Если она жаждет громких оваций мыслителей и восторга благородных, то ни угрожающая глупость, ни рычащая клевета не собьют ее с намеченного пути.

Сколь позорно то, что человеческий страх удерживает нас от нашего же образования, что толпа, - под какой бы маской она не скрывалась, - препятствует нашим попыткам приобщиться к прогрессу Просвещения и совершенствовать наше мышление и обычаи. Именно поэтому мы справедливо заслужили определение слабого пола, который из-за рабского страха не может воплотить в жизнь свои удивительнейшие добродетели. Наш зыбкий характер как будто сплетен из паутины, разорвать которую способно малейшее дуновение ветра. И такой характер по праву достоин порицания. -

Но нет! - Наберемся храбрости, мои дорогие читательницы! Давайте же посредством мысли поторопимся вперед, по- 


\section{Марианна Эрман Мое вступительное слово}

средством самопознания овладеем благом, с верой в славные принципы воспрепятствуем развитию слабостей, действуя и размышляя, отдалимся от предрассудков и, в итоге, с твердым убеждением добьемся чудесной цели! Давайте же усиленно работать над этой задачей, искренне признавать и исправлять наше неблагоразумие, выдерживать все сложности там, где дело касается нашего временного или вечного счастья. Проникнемся же мужской стойкостью и одержим победу! -

Моя добрая воля и бесконечная готовность оказывать поддержку помогут вам на этом нелегком пути. Скромные таланты, которыми наградила меня судьба, а также немного опыта, который скопился за мою жизнь, я с огромной радостью направлю на воплощение нашего намерения. Материал, который я для этого выбираю, отвечает моему представленному плану. Его широта и многообразие находятся в прямой зависимости от настроений и обстоятельств. Все, с чем я сталкиваюсь в повседневной жизни, будет приобщено к моей работе. И все же, я запрещаю себе любые личные трактовки и не думаю, что кто-либо будет всерьез воспринимать мою сатиру. Мой тон будет представлять собой смену жизнерадостности серьезностью, чтобы не злоупотреблять терпением и снисхождением моих читательниц. И самым большим счастьем для меня было бы быть принятой и зарекомендовать себя всем своим читательницам.

Издательница 


\section{Список источников и митературы}

\section{Источники}

Hippel. 1794 - Hippel T.G. Über die bürgerliche Verbesserung der Weiber. Frankfurt und Leipzig, 1794

Hippel 1801 - Hippel T.G. Nachlaß über weibliche Bildung. Berlin, 1801

\section{\ИТЕРАТУРА}

Böhmel-Fichera. 1992 - Böhmel-Fichera U. "Es Ist Ein Schön Gelese". Literarische Frauenzeitschriften Im Späten 18. Jahrhundert // Begegnung mit dem Fremden : Grenzen, Traditionen, Vergleiche (Akten Des VIII. Internationalen Germanisten-Kongresses; Bd.10) / Hrsg. E. Iwasaki. München, 1992. S. 212-221.

Querelles. 1996 - Querelles. Jahrbuch für Frauenforschung 1996, Band 1: Gelehrsamkeit und kulturelle Emanzipation / Hg. Ebrecht A., von der Lühe I. Einleitung. Stuttgart / Weimar 1996. S. 9-18.

Kirstein. 1997 - Kirstein B.-A. Marianne Ehrmann: Publizistin und Herausgeberin im ausgehenden 18. Jahrhundert. Wiesbaden, 1997. 